Specijalna edukacija i rehabilitacija

UDK: 376.1-056.263(4)"13/15"

(Beograd), Vol. 11, br. 1. 147-165, 2012.

ID: 189872140

Marina RADIĆ ŠESTIĆ ${ }^{1 *}$

Pregledni rad

Nadežda DIMIĆ*

Mia ŠEŠUM**

University of Belgrade

Faculty of Special Education and Rehabilitation*

Ministry of Interior $R S^{* *}$

\title{
THE BEGINNINGS OF EDUCATION OF THE DEAF PERSONS: RENAISSANCE EUROPE (XIV-XVI CENTURY)
}

The aim of this paper is to indicate a turnover of the society towards deaf persons which was brought by the historic Renaissance period, from the XIV to XVI century. It is well known fact that handicapped persons were marginalized in the Middle Ages by the broader social community and that charitable care within churches and monasteries was considered to be the only legitimate form of help to those who were designated by God to expiate the sins of their ancestors. The weakening of the church authority and the improvement of science in the $X V$ century lead to increased interest in medicine, that has also reflected on the attitudes of experts towards deaf people who started to be more actively interested in them. The Renaissance has begotten the first teachers of the deaf, as well as the first deaf artists who have been recognized and revered by society, and that had a crucial impact on the change of comprehension of deafness and attitudes towards the possibilities of the deaf. All this contributed to laying the foundations for more organized work with the deaf, which has occurred in Europe in the XVIII century.

Key words: society, renaissance, education, deaf pupil, deafness, sign language

1 E-mail: marina.r-s@hotmail.com 
Specijalna edukacija i rehabilitacija (Beograd), Vol. 11, br. 1. 147-165, 2012.

\section{INTRODUCTION}

The Renaissance is a cultural and historical concept which primarily denoted the period of predominantly Italian art, culture and science from the middle of the XIV to the beginning of the XVI century. It was conceived in the XIV century in the town-states of Northern Italy, who became rich and powerful owing to the development of trade during the Middle Ages. It caused the awakening of science and overcoming of laicism, as well as strong opposition of intellectuals and progressive people towards instances of restriction of human rights and development of science. Self-confidence and human intellect prevailed over submissive behavior characteristic of medieval uncompromising respect for God and God's word (Krleža, 1967: 439). Although Renaissance men in no way have rejected Christianity, they valued the earthly life to much greater extent than men in the Middle Ages, who have mainly been directed to the beyond world.

Only in Renaissance man again became the actuator, nucleus, purpose and participant of intellectual events and general progress. Thus Italy became the center of global historical turnover and for centuries remains a role model for the entire Europe owing to special renewal of Antique period in all domains of human creativity. At the same time, the Renaissance is a period of scientific development of all sciences, medicine as well, which has favorably influenced the study of problems of persons with disabilities and creation of advantageous conditions for practical work with them.

In the XV and XVI century, the ideas of the Renaissance have spread to Germany, France, Spain and England owing to numerous books which were available after the invention of the printing press, which has enabled their faster distribution, not only among the elite, as was previously the case, but among the "common folks" as well. Such increased interest for mass education of population had also a positive influence on the education of the deaf children (Van Cleve, 1993:240). 


\section{Relation to Deafness in Pre-modern Period}

Until the Renaissance, the deaf were treated as less worthy persons. Under the influence of the views of Aristotle and St. Augustine, who have considered that the deaf could not be educated, their training has not been acceded for a long time. Deafness as a medical and social problem was discussed only in various state legal acts and in medical documents. Speech was considered a gift of God, and a deaf child was deprived of speech by God's will. Only the Church was the intermediary between God and men. Thus was clearly defined the position of deafness, as well as the issue of rehabilitation of deafness as a disability. Deafness was then considered as such a severe disability that there is no chance to help or alleviate such condition. Only a miracle could help in case of deafness (Dimić, 1996:15).

Mediaeval philosophers and teachers considered the deaf people as a part of God's plan which they have no right to influence. Change of situation and status of the deaf was possible only with the God's intervention. There was a belief that the souls of the deaf can't find salvation, because theyare not able to hear the priest's sermon (Branson, Miller, 2002:67). Since they were often misunderstood, the fear of expulsion and elimination followed the deaf through the considerable part of their history (Padden, 2005:161). The deaf in the period of the Middle Ages, as well as at the beginning of the Renaissance have often served their landlords as a cheap labor. However, that was related only to the poor deaf, the children of aristocrats were accommodated in the monasteries where they were entrusted to the custody of monks. Considering that on the one hand the Church proclaimed mercy and on the other hand the existence of "predestination"- intention of the almighty that certain persons (the deaf, blind, physically disabled...) expiate the punishment for the sins of their parents, any effort for the purpose of educating the deaf, except for charitable care has not been tolerated. If by any chance someone would oppose this official standing that had existed in the Middle Ages, one could have been accused for heresy and burned at the stake. Only the high clergy had the right to interfere in predestination, because it was considered that its members have received a special gift from the almighty so that they can perform their duties. 
Specijalna edukacija i rehabilitacija (Beograd), Vol. 11, br. 1. 147-165, 2012.

It was in this period that a great historical paradox occurred: in the period of the most severe Inquisition, when all those who were considered to be opposed to the Church standings and had connection with the devil were burned at the stake, when even the blind were burned at the stake, the education of the deaf by the clergy commenced in the monasteries (Savić, Maslić, 1974:7). Some monks considered writing and gesturing to be the manners of achieving knowledge and salvation, because these forms of communication were represented in the monasteries in which many internal sign systems have been developed. These sign systems were not created because of the deaf, nor they have used it; they were developed by various monk orders for the purpose of their communication during the period of silence, when speaking wasn't allowed (Branson, Miller, 2002:68). The sign systems of the deaf grew out of the need of the biological imperative for the first, maternal language, and were independent from the sign systems which were used by hearing people (Bragg, 1997:15).

The monasteries also produced the first teachers who have taught by means of sign language. These teachers were dedicated not only to teaching reading and writing, but taught their students to talk as well, thus denying the centuries old notion that the deaf need a miracle to begin talking. In addition to the monks, physicians and teachers soon have begun teaching the deaf. The overall philosophical view of the world has changed in the Renaissance period; the goals of education have changed, as well as the expectations of individuals and society who after a thousand years long absolute reign of the Church wanted to take over the responsibility for their own prosperity. People no longer accepted the world itself, as a God-given, but they have started looking for a way to change it. As expected, that has affected the attitudes towards deafness as well.

Teaching the deaf children how to talk has become one of the new philosophical achievements, and it was a domain where the experts from all over Europe could prove that it is possible to change the course of human destiny. Although there were some isolated attempts of training the deaf in the past, only since the Renaissance begun systematic work of teachers and physicians with the deaf. New page in history and treatment of the deaf was opened, because in this historical period we have started with initial tolerance and, through 
sheltering, crossed to the concrete practice of rehabilitation (Branson, Miller, 2002:68).

\section{Abandonment of the Mediaeval Notion of Deafness}

Ancient medical science treated deafness as the influence of supernatural forces on the individual, so the physicians came to the conclusion that the deaf could not be rehabilitated. Later they have discovered that there is some kind of connection between deafness and muteness, but the clinical picture of deafness was not yet known. The renowned antique physician and philosopher Aelius Galenus (129199 AD), whose theories had a significant influence on the Western medicine for more than one millennium, concluded that deafness is a disease in which function of organism was impaired. The low level of science in the mediaeval period, and especially the anatomy and physiology, did not allow consideration of the causes and consequences of hearing impairment (Kovačević, 2003:9). However, the interest in the anatomy of men has increased at the beginning of the Renaissance; many autopsies that were performed in that time support that fact.

Among the first matters that have significantly influenced the new medical concept of the Renaissance period are the texts of Paracelsus (1493-1541) who was interested in reconsiderations of Galenus's dogma, as well as the two anatomy texts of Andreas Versalius, who have corrected some of Galenus's anatomical beliefs and laid the foundation for modern scientific studies of the brain. A physician Hieronymus Mercurialis was among those who were influenced by Versalius. He certainly considered that brain injuries, as well as other traumas, could be the causes of underdevelopment of speech and problems in articulation, to a lesser or greater degree. In his work Mercurialis unified the cognitions from the classical sources and his own practical experience. He thought that the congenital deafness is the major cause of underdevelopment of speech, and that the child who wasn't ever able to hear anything will be missing stimuli necessary for the brain to perform activation of articulatory organs. The connection between muteness and deafness was a subject of great interest of physicians in the age of the Renaissance. 
Specijalna edukacija i rehabilitacija (Beograd), Vol. 11, br. 1. 147-165, 2012.

The treatment of muteness was possible if a person didn't have impaired hearing, but the deaf were often considered incurable. A German physician Salomon Alberti (1540-1600) thought that hearing and speech impairment need not be necessarily connected and that Aristotle and Hippocrates were mistaken when they claimed that a hearing loss inevitably conditions loss of speech as well. Alberti pointed out that the physicians have for centuries relied on the conclusions from the ancient times and that this has affected the accumulation of wrong concepts and evaluations. He, on the other hand, relied solely upon his own practical experience. The autopsies which he has performed enabled him to become familiar with speech and hearing apparatus and to study the nerves and muscles necessary for mobilization of speech organs. Alberti claimed that the speech is a skill that it is adopted, and not a gift meant for people. Thereby he wanted to emphasize that the deaf and mute persons are completely rational, as well as everyone else. As a Renaissance man, Alberti believed in the soul, as well as that the man is a creation of God in his own model, but he didn't believe that hearing and speech impairment are the consequence of damage to the soul. He considered that congenital deafness is a consequence of fault of the period of embryonic development and that in no way it could be regarded as a punishment from God and influence the humanism of an individual. Starting from the assertions of Versalius and Alberti, many scientists from various scientific disciplines commenced studying problems of deafness. It was no longer the question of whether the deaf could be taught to speak, but which is the best way to do it. Various methods that could help to solve this problem were taken into consideration (Albrecht, 2006:864).

Rudolphus Agricolae (1444-1485) had an enormous impact on the spread of humanism in the late XV century (Tervoort, 2005:354). In his book „De Inventione Dialectica”, he described the encounter with a man who was deaf from birth and consequently mute, but nevertheless he managed to learn to understand everything written and express his thoughts, desires and intentions in writing (Van Cleve, 1993:241).

In 1575 a Spanish lawyer Lasso wrote that the deaf who were taught to speak are no longer stupid, and that they have the right to inheritance (Cagle, 2010). A French physician Laurent Joubert noted 
in 1587 that the teacher had to be very patient when it comes to teaching the deaf pupils to imitate characteristic facial expressions and movement of speech organs, but that the effort will show results because in that manner the deaf will succeed in developing speech despite hearing impairment (Van Cleve, 1987:42).

In 1603, Fabricius Aquapendente, a professor of anatomy at the University of Padua, published two papers that were in many aspects ahead of his time. They emphasized the existence of differences between so called pantomime, which has been used in Italy since ancient times, and natural gesture expression of the deaf. Aquapendente claimed that the training is necessary for understanding sign language of the deaf, and that language is much more complex than a mere imitation of reality by means of movements of arms and hands, as it was believed. He was the first person who denied the iconicity of the sign language. Also, he argued that the muteness of the deaf is solely a consequence of their inability of hearing. He believed that there is no possibility of curing congenital and postnatal deafness, but he advocated that the deaf children should be educated in the best possible way. He warned that no one should attempt to cure deafness by some problematic means, as it had previously been the custom, and that providing the best possible education to the child is the only way to overcome it (Savić, Maslić, 1974:62)

\section{The First Teachers of the Deaf}

A physician Girolamo Cardano (1501-1576) was considered to be the first representative of the scientific thought and the founder of theoretical concept of education of the deaf. Cardano was the first who publicly asserted that the muteness occurred as a consequence of deafness, which was a heavy blow to then religious dogmas of deafness as a divine punishment, which is why he was imprisoned by the Inquisition in 1573 and a lot of his books were burned. A well known is Cardano's notion that deafness could be neutralized by means of transmission of sound through the skull bones, if a deaf person and his collocutor during conversation hold a small stick in their mouths that will allow them to hear each other. Also, he was the first who gave a definition of hearing impairment according to the time of the 
Specijalna edukacija i rehabilitacija (Beograd), Vol. 11, br. 1. 147-165, 2012.

occurrence of that impairment and the degree of development of speech and the remainder of hearing. Cardano's greatest accomplishment is that he established that deafness is not a pathological phenomenon which causes inability of intellectual development and that the deaf, with proper training, can achieve a high intellectual level. He denied that the development of thinking is impossible without the ability to speak, pointing out that the deaf can "hear" by means of reading and „speak" by writing. Thereby he became the first physician who established the theory that the deaf can be educated. This thought, although lonely, because the tradition of the past is opposed to new notions, was a herald of the new views on deafness and possibilities for the rehabilitation of the deaf (Dimić, 1996:17).

He defied the ancient notion that persons who have not mastered the speech are without language, and therefore without a soul and reason as well (Van Cleve, 1987:246). The ideas presented in Cardano's professional works represent the foundations of the contemporary approach to education of the deaf and abandonment of generalized preconceptions about what the deaf can do, and what is unattainable to them (Marschark, Lang, Albertini, 2002:19).. Instead of the earlier caritative approach to deafness, he demanded, together with his contemporary, a physician Fabricius Aquapendante, the education of the deaf, because they considered that a deaf person cannot achieve mastering of speech alone, in a natural way, but a special organized training is necessary for that. The ideas of Cardano about the possibility of intellectual development and education of the deaf found their confirmation and further expansion of individual education of the deaf in practice which was created in Spain, one of the largest, wealthiest and the most developed countries of Europe in the XV and XVI century, and then transferred to the Netherlands, England, France and Germany, soon to be extended to the entire Europe (Savić, Ivanović, 1994:14,15).

The Benedictine monk Pedro Ponce de León (1508-1584) is believed to be the first teacher of the deaf. Shaken by the handicap of two boys who stayed in the same monastery as he, Ponce tried to find a way that would allow him to train them. It is considered that the method that he used in his work was based on writing, with finger pointing to the objects that are named, than inducing movement 
of the tongue and lips which correspond to the pronunciation of written sounds, usage of the finger alphabet, and then writing them down by the deaf pupils. He was the first who in his work with the deaf persons used finger alphabet, which had appeared for the first time in that context in historical documents in the XVI century, in the notes of Melchor de Yebra (1526-1586) (Plann, 1997). Ponce also communicated with his pupils by means of gestures, considering that the monks of his monastic order were under the strict vow of silence. Since his method proved to be effective, he also started to teach the other deaf persons, who were predominantly from the wealthy and respectable families (Van Cleve, 1987:295-297). In order to escape the conviction of the Inquisition, he claimed that he had received a special gift from St. Ignatius Loyola, so that he could train the deaf. The other early teachers of the deaf resorted to that as well, because there was a danger that they could be accused in front of the Inquisition for quackery and witchcraft (Savić. Maslić, 1974:7). Through his work he has proved that even the deaf can read, write, think and speak (Plann, 1997). It is considered that Bonet and Carrion, who were after Ponse also engaged in teaching the deaf to speak, relied a great deal exactly upon his work methods.

Manuel Ramirez de Carrion (1579-1652) was a teacher and one of the pioneers of education of the deaf, who is considered as a direct successor of Pedro Ponce de León. Carrion started with the training of the deaf in his native Spain, where he published a book „Miracles of Nature" (Maravillas de naturaleza, 1629), some kind of Encyclopedia, where he partially described his vocal method with which he trained the deaf to read and write, and also he presented his reflections on possibilities of their education. In 1636 he went to Italy and stayed there till 1645, when he returned to Spain, where after 1652 every trace of him was lost (Bojanin, Blagojević, Buljančević i sar., 1999:164). Carrion, as well as the majority of teachers of those times, tried to keep his method secret, in an attempt to avoid the appearance of competition, and also to maintain the privileged position which he enjoyed among the nobility that was interested in his services.

He noticed that the underdevelopment of speech among the deaf is a consequence of the lack of auditory stimulation, and considering that their speech organs are completely functional, it is possible to 
Specijalna edukacija i rehabilitacija (Beograd), Vol. 11, br. 1. 147-165, 2012.

teach them to speak. Carrion's method was most probably based on learning the letters according to the sounds they represent, and not according to their regular names. This method was called the reduction of letters. The reduction of the names of letters and their connection solely with the sounds they represent was likely practiced by both Ponce and Bonet in their training of the deaf. In his communication with the deaf pupils Carrion also used the finger alphabet that he most probably took over from Bonet, with minimal modifications (Van Cleve, 1987:179-180). In order to give medical character to his work in the period of Inquisition, respectively that his treatments would not resemble the miraculous returning of the ability of speech to the deaf, because of which he could be convicted and burned at the stake, he was giving his pupils laxatives and other various potions, shaved their heads and smeared various ointments on shaven places, and then articulated sounds, syllables and words in the crowns of their heads, which were then repeated by their pupils. This was the first attempt of learning to speak by means of transfer of sound through bones caused by vibration of the head (Bojanin, Blagojević, Buljančević i sar., 1999:164). Owing to large number of the deaf that he has successfully educated, Carrion is considered to be the most significant successor of Pedro Ponce de León in the history of education of the deaf. Nevertheless, his method became well known only when it was described and published by Bonet in 1620 .

Juan Pablo Bonet (1579-1623) was a Spanish teacher and author of the first book completely dedicated to education of the deaf. Bonet was able to observe Carrion teaching the deaf children, so he adopted his method and got into education of the deaf himself. He hasn't invented any new method of work, yet he only applied what he had learned from Carrion. In 1620 he published a book „Simplification of the Alphabet, and the Art of Teaching Mutes to Speak" (Van Cleve, 1987:263, 264). This book has two parts: the first one is a descriptive phonetics of Spanish language, and the second part is the methodology of working with the deaf, where he laid out numerous principles of education of the deaf, by which he set the foundations of the articulative teaching. The descriptions of the articulative positions in this book were extraordinary, and helped contemporary phoneticians to comprehend articulation of Spanish language of the seventeenth century. 
Also, Bonet was the first who insisted on the difference between audible and inaudible sounds. He believed that studying reading and spelling is completely justifiable, and that, if a child knows how to articulate every letter and how to attach it to the expiration of the sound, it could accomplish to read out loud in a very short time, although this does not mean that it would necessarily understand everything it reads. Juan Pablo Bonet died in 1623, in Madrid. Although he wasn't the author of the method of teaching the deaf, the book he had written was very significant for the expansion of the idea that the deaf can be taught oral speech. His work with the deaf served as an inspiration also to the other European teachers interested for this type of education as well.

\section{The Deaf Artists}

The deaf people who were involved in the literary arts have always used various literary forms in their expression, and traditionally the most frequent theme they were writing about was experience of deafness. A Spanish nun Teresa de Cartagena, as well as French Renaissance poets Pierre de Ronsard and Joachim du Bellay had especially significant influence of the literature of the deaf. The figure of Teresa de Cartagena was exhibited at the oldest known portrait of the deaf person, dated from 1453. In her youth Teresa fell deaf, after which she became a nun and devoted her life to writing. Although she suffered because of her handicap, she perceived it as a temptation, and in her texts tried to share her own experience of deafness with her readers, as well as to advise and provide comfort to other deaf people.

The significance of her works is reflected in a revolutionary idea of acceptance of the handicap not as a punishment, but as a blessing, as well as in the fact that in the XV century it was uncommon to write about bodily suffering, especially when the woman is in question. Teresa believed that the deafness is a gift from God, which was given to her so that she could be closer to him, and she wanted to share that belief with other persons with disabilities as well (Abel, 1980:187). Her texts were often considered controversial, because she wrote about the gender equality and birth roles, and her text „Admiraçión operum Dey” („Wonder at the Works of God”) is considered by many 
Specijalna edukacija i rehabilitacija (Beograd), Vol. 11, br. 1. 147-165, 2012.

historians to be the first Spanish feminist tractate (SeidenspinnerNúñez, 2004:15-20)

The Renaissance artists used religious themes, but at the same time they have shifted attention from the sky to the nature and man, thus questioning the superiority of faith over art. Extraordinary Renaissance artists effortlessly portrayed characteristics of people and celebrated corporal form of men. Renaissance art developed also a new concept of visual space, which was defined from the standpoint of individual observer. Cultural goods of the ancient world were revived and accepted together with the new values in an attempt of faithful representation of reality.

An insight into the interest of artists of these times can easily be achieved on the basis of the work "The Notebooks of Leonardo Da Vinci". Besides anatomy, proportions, perspective, light and shadows, painters of those times were also interested in questions such as: how to accurately portray the posture of the model, his gestures, emotions, body in movement...(Davies, 1961). In addition to accurately portrayed the physiognomy of painted people, the Renaissance painters have tried to show their feelings as well. The Italians believed in wisdom and beauty, and idealization of human body and face was one of the fundamental characteristics of the Renaissance art, which it inherited from the ancient world. In the period of the Middle Ages and Renaissance it was hard to find a deaf person that knew how to read and write, but nevertheless many deaf people lived productive lives. The proof for that were numerous deaf painters who in the XVI century created exceptional works and through their work left significant mark in the history of art.

The ability of artistic expression of the deaf has been noted a long time ago; famous Leonardo da Vinci and Girolamo Cardano also wrote about the artistic talents of the deaf. They have believed that painting was an exceptional domain in which the deaf could express themselves, because one does not need to have components of speech and hearing for that. Cardano considered that great artists do not need to bother painting large areas in churches when that could be done by the deaf, and masters can only finalize their works by instilling a soul in them.

The first mention of the deaf painters date as early as the Roman period, and the first deaf painter was Quintus Pedius, a grandson of 
the Roman consul, who entered all encyclopedias of painting. The Spaniard Juan Fernandez de Navarrete (1526-1579), called El Mudo (The Mute) was the first court painter of the King Philip II, the most prominent one in a group of Spanish and Italian painters who worked at Escorial. The majority of his artistic opus consists of portraits of distinguished religious figures. Characteristic for El Mudo's style is his endeavor to depict human feelings. In the history of art he was remembered as an educated artist, freethinker and innovator, as well as the first painter in Spain who virtuously used the contrasts of dynamic light and darkness in the tradition of Tintoretto, which he has modified and adapted to the Spanish realism. El Mudo suddenly fell deaf in his early childhood, at the age of 3 and a half. He compensated his inability to speak with drawing, and thus developed his own way of communication with the environment. Navarette learned history and studied the Bible in the monastery, more than a decade before Ponce de León started to train the deaf (Marschark, Lang, Albertini, 2002:20). He acquired artistic education in Spain and Italy, after which he spent several years working on the restoration of Escorial, and from 1568 he gained the title of court painter. His paintings exuded energy and preciseness, with very free usage of contrasts of light and darkness. His evolution as an artist, although not rapid and radical, was under the influence of the continuous search for new manners to enrich of his own style (Van Cleve, 1987:236).

Bernardino di Beto di Biaggio „Pinturicchio“ (1454-1513) was a deaf Italian Renaissance painter, known as an extraordinary master of the fresco technique. In his compositions he portrayed a variety of Biblical themes with a large number of characters in landscape and architectural ambiances, in vivacious coloring and gilding. In Rome he painted cycles of frescoes in the churches Santa Maria del Popolo and Santa Maria in Aracoeli, as well as in the apartments of Pope Alexander VI at the Vatican. He collaborated with Pietro Perugino painting the frescoes in the Sistine Chapel. Outside Rome he painted frescoes in the hall of the Cathedral of Orvieto and in the library of the Cathedral of Siena (Krleža, 1967:134).

Ercole Sarti (1593 -1639) was an Italian painter, known by his nickname Il muto de Ficarola (The Mute from Ficarola), because of the underdeveloped speech, which was most probably a consequence 
Specijalna edukacija i rehabilitacija (Beograd), Vol. 11, br. 1. 147-165, 2012.

of congenital deafness. He painted in Felonica and in Salara as well. In the Ficarolo's St. Valentine Church he painted a well known work "Crucifixion with Donor and Saints Valentine and Carlo Borromeo" (Laderchi, 1856:157). The work of Jaime López, a deaf Spanish painter, known for his nickname El Muño was also noticed in the XV century in the period of the early Renaissance. „St. John the Baptist in the Church of Toledo" was his famous painting. He was also known for his decorating the Hermitage of our Lady of Prado (Bryan, 2007:75). Hendrick Barentsz Avercamp (1585-1634) was a well known Dutch painter, who became famous for painting winter landscapes in oil painting technique. He was the author of numerous works which were even to this day preserved in various galleries or private collections. Jean le Muet and Berend Dircksz were distinguished Flemish painters, who, as well as many other renowned artists of that period, fell deaf in their childhood.

Cristiforo de Predis (1440-1486) was yet another Italian Renaissance painter, who was deaf from birth. In his work he has combined an elegant and refined artist's style with the Renaissance motifs that have thus obtained the reality. He was known for illustrating the "Borromeo Book of Hours”, where, although there is a signature of the author, creation date has not been specified (Clarke, Clarke, 2002). However, his most famous work is artistic illustrations in the book "De Sphaera d'Erste” (around 1470), which is even today considered as the most beautifully illustrated astrology book from the Renaissance period. All illustrated scenes are in the context of the leading theme of the book, the planet. The astronomical motifs were illustrated in the manner similar to the contemporary astrological maps. The book contains a total of 15 luxurious miniatures, each painted across the entire page. The illustrations exhibit planets, which, according to the conceptions of that period, were turning around the Earth and that were: Saturn, Jupiter, Mars, Sun, Venus, Mercury and the Moon. These astronomical maps also showed the position of Earth in relation to the celestial bodies and provided explanations for the Moon phases and climate coordinates as well. Every planet is associated with a specific Zodiac sign, as well as with two marvelous presentations of landscape, town or interior each, painted in a very realistic manner. These miniatures precede and follow astronomical 
drawings which illustrate astronomical situations on visible parts of the sky and represent fantastic accomplishments of the Renaissance.

The accomplishments of talented deaf persons in the Renaissance period are the proof that the deaf people even without organized training found the way to communicate with their environment. Their results represent the first indications of the possibilities of successful training of the deaf through education (Marschark, Lang, Albertini, 2002:20).

By creating artistic works the deaf persons demonstrate their intellectual capacities and contradict the popular belief that they are the „primitive” and non-productive members of society (Mirzoeff, 1995:3). The role of art in the Renaissance period could not be underestimated at all. It is not only the means for the deaf persons to prove their values and abilities, but it is also an „activism which helps the deaf persons to express their identity." (Mirzoeff, 1995:12)

\section{Instead of the Conclusion}

Regardless of the enormous progress in the education of the deaf which was brought by the Renaissance, all the attempts of their education from this period were individual, isolated and sporadic efforts of the philanthropists or physicians who have trained one or more deaf children and left direct or incidental record of their method. Since pupils were mostly children from the families that belong to the ruling class, the ideology of that class determined the goal of upbringing and education of the deaf, and it was mastering speech for the purpose of communication with the environment which consisted of hearing people.

Through the entire Renaissance period no overall educational system was developed, nor has the broader final goal of the education of the deaf been established. Everything amounted to mastering oral speech within the boundaries of individual possibilities. Every author considered his method the best and unique, by which one could achieve the best results (Savić, 1966: 64). Nevertheless, the general social change which was brought by the Renaissance, thanks to the scientific approach to the problem of deafness, as well as to the extraordinary deaf individuals who made humanity their debtor for their work and 
thus proved that they are capable for productive life and work, made possible to lay the foundations for the organized educational work with the deaf which has appeared in Europe in the XVIII century.

Also, the Renaissance exploitation of visually-kinesthetic communication systems represents the beginning of their acceptance and is essential for their modern history, as well as the position they have in the contemporary world (Bragg, 1997:24). Two courses have developed during the period which followed the Renaissance, whose representatives were the physicians that tried to merge medicine with pedagogical procedures in their work with the deaf children.

The representatives of the English course developed the teaching of the Spanish school, so that they, besides speech also used writing, finger alphabet and gesture in their work, while the representatives of the Dutch course developed their own system of training the deaf based on the application of oral speech exclusively. However, in terms of individual training of the deaf no one felt the need to organize special institutions for their training, considering that all children that have been trained by then were from the aristocratic families, who didn't care for the overall education of the deaf.

\section{LITERATURA}

1. Abel, E. (1980). On Female Identity and Writing in Women, University of Chicago Press.

2. Albrecht, L.G. (2006): Encyclopedia of Disability, University of Illinois, Chicago.

3. Bojanin, S., Blagojević, D., Buljančević, M. i sar. (1999). Defektoloski leksikon, Zavod za udžbenike i nastavna sredstva, Beograd.

4. Bragg, L. (1997). Visual-Kinetic Communication in Europe before 1600: A Survey of Sign Lexicons and Finger Alphabets Prior to the Rise of Deaf Education, Journal of Deaf Studies and Deaf Education 2 (1) 15-24.

5. Branson, J., Miller, D. (2002). Damned for their Difference: The Cultural Construction of Deaf People as Disabled A Sociological History, Washington, D.C. 
6. Bryan, M. (2007). Dictionary of Painters and Engravers, Biographical and Critical (Volume II L-Z) (London, 1889); Original from Fogg Library, Digitized May 18, 2007: George Bell and Sons.

7. Cagle, K., M. (2010). Exploring the Ancestral Roots of American Sign Language: Lexical Borrowing from Cistercian Sign Language and French Sign Language, The University of New Mexico Albuquerque, New Mexico, dissertation.

8. Clarke, M., Clarke, D. (2002). The Concise Grove Dictionary of Art Terms, Oxform University Press.

9. Davies, M. (1961). National Gallery Catalogues: Catalogue of the Earlier Italian Schools, National Gallery Catalogues, London.

10. Dimić, N. (1996). Metodika artikulacije, Defektološki fakultet, Beograd.

11. Kovačević, J. (2003). Didaktički sistemi u školovanju gluvih, DDJ, Beograd.

12. Krleža, M. (1967). Enciklopedija leksikografskog zavoda, vol 5, Zagreb.

13. Laderchi, C. (1856). La pittura ferrarese, memorie, Ferrara, Italy.

14. Marschark, M., Lang, H. G., Albertini, J., A. (2002). Educating Deaf Students from Research to Practice, Oxford University Press, New York.

15. Mirzoeff, N. (1995). Silent Poetry: Deafness, Sign, and Visual Culture in Modern France. Princeton, New Jersey: Princeton University Press.

16. Padden, Carol A., Tom, L. Humphries (2005). Inside Deaf Culture. Cambridge, MA: Harvard University Press.

17. Plann, S. (1997). A Silent Minority: Deaf Education in Spain, 1550-1835. University of California Press, Berkeley.

18. Savić, Lj., Maslić, F. (1974). Pregled opšte istorije surdopedagogije, Defektološki fakultet, Beograd.

19. Savić, Lj., Ivanović, P. (1994). Surdopedagogija, Defektološki fakultet, Beograd. 
20. Savić, Lj. (1996). Teorija i praksa specijalnog školstva u Srbiji do drugog svetskog rata, Savezni odbor Saveza gluvih Jugoslavije, Beograd.

21. Tervoort, A. (2005). The Iter Italicum and the Northern Netherlands: Dutch Students at Italian Universities and their Role in the Netherlands' Society (1426-1575), Leiden and Boston: Brill Academic Publisher.

22. Van Cleve, J. V. (1987). Gallaudet Encyclopedia of Deaf People and Deafness, vol 1, vol 2, New York: McGraw-Hill Book Company.

23. Van Cleve, J. V. (1993). Deaf History Unveiled: Interpretations from the New Scholarship, Washington, D.C.Gallaudet University Press. 


\title{
POČECI OBRAZOVANJA GLUVIH OSOBA: RENESANSNA EVROPA (XIV-XVI VEK)
}

\author{
Marina Radić Šestić*, Nadežda Dimić*, Mia Šešum** \\ Univerzitet u Beogradu \\ Fakultet za specijalnu edukaciju i rehabilitaciju* \\ Ministarstvo unutrašnjih poslova $R S^{* *}$
}

\section{Sažetak}

Cilj ovog rada je da ukaže na preokret u odnosu društva prema gluvim osobama koji je doneo istorijski period renesanse, od XIV do XVI veka. Poznato je da su u srednjem veku hendikepirane osobe bile marginalizovane od strane šire društvene zajednice i da se smatralo da je milosrdno zbrinjavanje pri crkvama i manastirima jedini legitiman oblik pomoći onima koje je Bog odredio da ispaštaju grehe predaka. Slabljenje autoriteta crkve i napredak nauke u XV veku dovode do pojačanog interesovanja za medicinu, što se odražava i na stavove stručnjaka prema gluvim osobama, za koje počinju aktivnije da se zanimaju. Renesansa je iznedrila prve učitelje gluvih, kao i prve gluve umetnike koji su bili priznati i cenjeni od strane društva, što je presudno uticalo na promenu shvatanja gluvoće i stava prema mogućnostima gluvih. Sve ovo je doprinelo postavljanju temelja za organizovani edukativni rad sa gluvima, koji se u Evropi javlja u XVIII veku.

Ključne reči: društvo, renesansa, obrazovanje, gluve i nagluve sobe, znakovni jezik

Primljeno: 9.01.2012.

Prihvaćeno: 20.2.2012. 